\title{
"LOS PHISICOS MODERNOS QUASI TODOS SON COPERNICANOS". COPERNICANISM AND ITS DISCONTENTS IN COLONIAL RÍO DE LA PLATA
}

\begin{abstract}
This paper distinguishes four perspectives in the process of reception of Copernicanism in colonial Rio de la Plata: (a) the discussion of the systems of the world in the University of Córdoba by the Jesuits until 1767; (b) the treatment of this topic by the Franciscans in Córdoba and in their convent school in Buenos Aires; (c) the teaching by the secular clergy in the Colegio de San Carlos in the same city; and (d) the celebration of Copernicus by the enlightened naval engineer Pedro Cerviño in the Nautical School of the Consulado de Buenos Aires The examination of these cases on the basis of manuscript courses and colonial printings shows that the reception of Copernican theory was an erratic process rich in incidences.
\end{abstract}

\section{Key words}

Copernicus, Spanish American Enlightenment, Newtonianism, Jesuit science, colonial science in Río de la Plata. 
Miguel de Asúa

Consejo Nacional de Investigaciones Científicas y Técnicas

Universidad Nacional de San Martín (Argentina)

mdeasua@retina.ar

Home address: Estanislao del Campo 324 (1706) Haedo, Pcia. de Buenos Aires, Argentina Phone: 541146585104

Miguel de Asúa holds a senior research position at the National Research Council for Science and Technology (Argentina) and is Professor of History of Science at Universidad de San Martín (Arg.). He received his M.D. from Universidad de Buenos Aires, an S.T.L. from Universidad Católica Argentina and his M.A. and Ph.D. from the University of Notre Dame. A former Guggenheim Fellow, Life member at St. Edmund's College (Cambridge) and Clare Hall (Cambridge), and full member of the Academia Nacional de la Historia (Arg.), he has been visiting scholar/fellow at Harvard, Yale and The Jesuit Institute, Boston College. He is the author of several books, among which A New World of Animals. Early Modern Europeans and the Creatures of Iberian America (Ashgate, 2005; in collaboration with Roger French) and Science in the Vanished Arcadia. Knowledge of Nature in the Jesuit Missions of Paraguay and Río de la Plata (Brill, 2014). At present he is working on a book on science, religion, and secularism in Argentina (1750-1960) for which he has signed contract with De Gruyter (Berlin).

Funding: research for this paper has been supported by CONICET (Argentina). 
The arrival of the Copernican picture of the world in Río de la Plata was a long and meandering process that spanned from mid-eighteenth century to the first decade of the nineteenth century. This makes a contrasts to what happened in the large political and cultural centers of colonial Spanish American. The acceptance of Copernicanism in Perú presupposed the fertile soil of a long established local astronomical tradition. ${ }^{1}$ In the viceroyalty of New Granada and in Quito, the arrival of Copernican theory was a consequence of the scientific expeditions chartered by the crown in the wake of the Bourbon reforms. ${ }^{2}$ In Río de la Plata, a southern outpost of the Spanish empire, the Copernican system was elaborated and discussed in different settings: the University of Córdoba, the Franciscan convent and the Colegio de San Carlos in Buenos Aires, and the nautical school of that port city. ${ }^{3}$ Jesuits, friars, priests, and functionaries of the crown were involved in studying and expounding the Copernican view of the universe. Some of them saw themselves as representatives of Enlightenment while others followed the proved ways of tradition.

It is well known that in 1758 pope Benedict XIV removed from the Index the general ban on Copernicanism ("all books teaching the earth's motion and the sun's immobility") but left the specific names of the prohibited authors (Copernicus, Foscarini, Zuñiga, Kepler, and Galileo), so that the strictures concerning the teaching of De revolutionibus held sway during the last decades of the colonial period (up to 1810) in the region under consideration. ${ }^{4}$ The clerics who taught in the cities of Córdoba and Buenos Aires were obviously aware of the seriousness of this prohibition: those who looked with favor upon the Copernican system resorted to the consecrated practice of teaching it as a hypothesis. But there were other ways in which Copernicus was dealt with by the different religious groups on which the transmission of academic culture rested, such as the Jesuits, the Franciscans, and the secular clergy.

In the years preceding the revolutionary political break of the provinces of Río de la Plata from Spain (1810) a vital public culture of science thrived in Buenos Aires, a port of call of southern Atlantic sea routes open to the arrival of new ideas. ${ }^{5}$ New researches have shown that the censorship of the Inquisition on books and the control of reading was a somewhat lax affair in those lands, where during the second decade of the eighteenth century prohibited books could be found in many libraries. ${ }^{6}$ It comes as no surprise that in this atmosphere of moderate enlightenment heliocentric theory could be publicly held. The first registered pronouncement in favor of Copernicus was apparently an open lecture in 1806 by Pedro Cerviño, a Spanish naval engineer in charge of the nautical academy founded in the years that preceded the revolution of independence. But the main reason for accepting Copernicanism was not necessarily the adscription to an enlightened program of ideas-although it was the latter which paved the way for its public proclamation. The Jesuit teacher Benito Riva discussed and defended the Copernican system by way of hypothesis in his course taught in Córdoba in the decade of 1760s. After the expulsion of the Society of Jesus in 1767, there was a wide spectrum of opinion as regards Copernican theory among the Franciscan friars and the secular priests, ranging from rejection to mild approval.

In what follows we will examine a few episodes of the reception of Copernicanism in Río de la Plata. Far from constituting a straightforward trend from obscurantism to Enlightenment, reception of Copernicus in Río de la Plata was an erratic process, with many incidences and in which technical expertise and adscription to a determinate philosophy of nature could be more important than the fact of belonging to a particular religious order. Following the usage in the body of writings upon which this analysis depends, I will utilize the terms "Copernican theory" and "Copernican System" interchangeably; "Copernicanism" is also used in a loose sense, to 
refer to the treatment of Copernicus' system of the world as discussed in the handbooks of natural philosophy used by the authors under consideration.

\section{The University of Córdoba in the Jesuit period}

The University of Córdoba, created and governed by the Jesuits, reigned as the main center of learning in Río de la Plata during colonial times. ${ }^{7}$ The school followed the usual scholastic curriculum and granted degrees in philosophy and theology. Formal teaching of mathematics was introduced in the 1760s, with the naming of the Jesuit cartographer and explorer José Quiroga as occupant of the corresponding chair. But there are no testimonies that it was ever put into effect. ${ }^{8}$ The course of natural philosophy was assigned to the second year of the cycle of philosophical studies.

By the middle of the seventeenth century, the teaching of philosophy in Córdoba had been based upon the works of the sixteenth-century Jesuit Antonio Rubio. Rubio's outlook obeyed the injunction of the Ratio studiorum (the educational charter of the Society of Jesus, 1599): it was entirely scholastic and Aristotelian. ${ }^{9}$ The following decades saw little renovation. We should remember that during the late seventeenth and early eighteenth centuries, Jesuit teaching of natural philosophy in Europe was shaken by the anti-Cartesian polemic. ${ }^{10}$ It was the $16^{\text {th }}$ general congregation of the Society of Jesus (1731) which opened a creak for the introduction of experimental natural philosophy and mechanical science into the traditional Aristotelian matrix - and even so, the decrees insisted on the teaching of Peripatetic philosophy. ${ }^{11}$ Certainly, the Provincial of the Jesuits in Río de la Plata received the circular letter from 8 November 1732 sent by the Superior General Retz with a list of ten prohibited propositions of natural philosophy, all of them concerning atomism and Cartesianism. ${ }^{12}$ The $17^{\text {th }}$ general congregation (1751) maintained the balance between a reluctant acceptation of mechanical philosophy and stern reaffirmation of tradition. It consecrated the distinction and the lack of conflict between physica generalis (Aristotelian natural philosophy) and physica particularis (experimental physics) while simultaneously prescribing the exposition and defense of the Aristotelian system and the use of the syllogistic way of exposition even for "particular physics". ${ }^{13}$

The Jesuits of Córdoba were aware of the novelties in experimental natural philosophy, as discussed in the works of French Jesuit Cartesians, German advocates of mechanical philosophy, and Spanish novatores. The index of the library of the University of Córdoba compiled in 1757 confirms the Jesuit penchant for eclecticism. It mentions Descartes' Opera omnia and works by Emmanuel Magnan and Jacques Rohault. ${ }^{14}$ There was also Jean Seguens' Atomismus demonstratus et vindicatus (Toulouse, 1715), one or more volumes of Pierre Gassendi's Opera (Lyon, 1658), and almost all the works on natural and mechanical philosophy by Gaspar Schott. ${ }^{15}$ With respect to Newtonian bibliography, the library of Córdoba held John Keill's Introductio ad veram physicam (Oxford, 1701). It is possible that other Newtonian books circulated in Jesuit libraries of the province, such as James Ferguson's Astronomy Explained Upon Sir Isaac Newton's Principles, second edition (London, 1757). ${ }^{16}$ It has been argued that the incorporation of Newton's Opticks and Principia in the courses of natural philosophy in the Río de la Plata consisted in the addition of fragments of experimental science to a basically scholastic discourse, without discussion of the founding notions of Newtonian natural philosophy and the mathematical worldview it implied ${ }^{17}$ It is unlikely that any teacher in the Río de la Plata had a first-hand knowledge of Newtonian science. As I have shown elsewhere, Furlong's claim that the English Jesuit doctor Thomas Falkner had been Newton's "favorite disciple" is unfounded and inconsistent even with the dates of the 
protagonists. ${ }^{18}$ The person best qualified to grasp the technicalities of Newton's work was Buenaventura Suárez, the Jesuit astronomer in the missions of Paraguay, and even he relied on secondary literature. ${ }^{19}$ The library of Córdoba included Clavius' commentary of Sacrobosco's Sphaera (Venice, 1601) and the edition by Franciscus Iunctinus (Lyon, 1578). ${ }^{20}$ It also held Clavius' Opera, the five volumes of Christian Wolff's Elementa Matheseos mathematica, mathematical works by José Zaragoza and the Compendio matemático ( 9 vols.) and Compendium philosophicum (5 vols.) by Tomás Vicente Tosca (both Zaragoza and Tosca were part of the group known as the novatores, who strove to introduce some modern science in Spain). ${ }^{21}$ Other lists show more books related to astronomy, such as Pierre Bouguer, La figure de la terre (Paris, 1749) and volumes 1, 2, 5, and 6 of the Acta Academie Scientiarum Imperialis Petropolitanae ${ }^{22}$ Vincent Wing's Astronomia Britannica (London, 1669) and Philippe de la Hire's Tabulae astronomicae (Paris, 1727). ${ }^{23}$

A manuscript with notes by a student taken from a course of physics (general and particular) dictated by Benito Riva (also spelled Riba, 1727-1800) in Córdoba in the 1760s has been conserved. ${ }^{24}$ Riva had been born in Catalonia, joined the Jesuits in 1746 and studied philosophy and theology in Río de la Plata. Between 1762 and 1764 he taught philosophy in Córdoba and afterwards worked as a missionary in the reduction of San José, among the Chiquitos (presentday Bolivia) until he left the country with the expulsion of $1767 .{ }^{25}$

In his introduction to the course, Riva extolls the novel paths opened by the "new philosophy" and the experimental approach to natural philosophy favored by Descartes, Gassendi, and Boyle; but he also reminds his students that this new philosophy never reached the height of the ancient. ${ }^{26}$ Essentially, the course expounds in scholastic fashion the different systems of natural philosophy (Aristotelian, Cartesian, Newtonian, and atomistic). Riva shows himself at times critical of Peripatetic natural philosophy and inclined to defend Cartesian and atomistic positions. He thinks of prime matter in terms of indivisible atoms or corpuscles and defends that heat is the result of the movement of the particles of which the bodies are composed. The final part of the course corresponds to a short treatise De mundo et caelo. ${ }^{27}$ After a sketchy overview of cosmology, Riva addresses the systems of the world. He ignores the Ptolemaic system, dispatches Tycho's in a pair of paragraphs, and devotes the rest of his lecture to the Copernican system. His brief description is organized upon the order of the planets and their periods of revolution around the Sun.

Much of what Riva has to say about Copernicus is taken from two of the Cartas eruditas $y$ curiosas [Epistles Scholarly and Curious] by Bernardo Feijóo, which circulated widely in colonial Río de la Plata. ${ }^{28}$ The Benedictine Feijóo, perhaps the most famous representative of Spanish Enlightenment, prided himself in being a follower of Newton but had an ambiguous position towards Copernicanism. ${ }^{29}$ In his first essay on the subject (1750), he claims that were it not for the authority of Scripture, he would be "the finest Copernican in the world"; but immediately after he tells the reader that the best thing to do would be to follow Tycho. Moreover, the letter ends with an addendum containing an argument derived from parallax to invalidate heliocentrism. ${ }^{30}$ Despite this ambivalence and his insouciant essayistic style, Feijóo's letters were perhaps the closest to an open discussion of the world systems that could be found among the recognized authors of the Iberian world.

Riva opens his discussion of Copernicus with the only sentence in Spanish in a course dictated in its entirety in Latin: "Los phisicos modernos casi todos son copernicanos" [Almost all modern physicists are Copernicans]. The sentence was quoted literally from Feijóo, who in turn took it from a review in the Journal de Trévoux of Robert de Vaugondy, Abrégé des 
différents systèmes $d u$ monde (Paris, 1745). ${ }^{31}$ Riva's shift to the tongue of everyday life in Río de la Plata could have been used to signify that he was talking "off the record" or could have meant an added emphasis - it could also be that he was just reproducing the Spanish of his source. In any case, he also follows in the steps of Feijóo when he affirms that the Copernican system has been taught publicly in the Collegium Romanum by the Jesuits, in particular by Roger Boscovich. ${ }^{32}$ The fact that the Mémoires de Trévoux and the Collegium Romanum were hallowed institutions of the Society of Jesus probably had a considerable weight with Riva.

The Jesuit teacher in Córdoba advances a number of arguments in favor of the Copernican system, all of them taken from Feijóo: ${ }^{33}$ (1) it is more economical to suppose that the Earth rotates in 24 hours than to admit a complete revolution of the whole firmament in that period; (2) if the Earth were immobile, its magnetic force ("virtus magnetica") would be in vain, for its purpose is to keep the poles of the planet aligned with the poles of the universe; (3) in the solar system, it is a rule that the smaller celestial bodies revolve around the larger, so the Earth should revolve around the Sun; (4) the Copernican system explains the retrograde movement of the planets without the cumbersome apparatus of eccentrics and epicycles. Riva gladly delved upon Feijóo to underpin his Copernican position, but he was far from sharing the latter's enthusiasm for Newtonian natural philosophy. The Jesuit rejects such basic Newtonian postulates as the mutual attraction of the bodies and the force of gravity, on account of it being an "occult force" which cannot explain anything: "Displicet quod hec virtus attractiva occultior est qualitatibus occultis". ${ }^{34}$

What comes next in Riva's course is a series of objections against the Copernican system and their solutions, summarized from the corresponding section in the volume devoted to cosmology in Tosca's Compendium philosophicum. ${ }^{35}$ Tosca's own position is nuanced. After refuting four Copernican arguments, he concludes that they are not conclusive. But he then goes through eight anti-Copernican objections and also finds them inconclusive. His final approved proposition is that "the Earth moves neither with diurnal motion nor with an annual motion through the Ecliptic" for which he calls in support the failure of the Copernican arguments and also the last two anti-Copernican ones, now rehabilitated (that all gravia should tend to a fixed center and the lack of detectable parallax). But he significantly adds that the immobility of the Earth is demonstrated praecipue (this adverb seems to be the key to Tosca's position) by the testimony of Scripture. The conclusion of the whole discussion is that, even if it is false that the Earth moves and the Sun does not, "if we accept the Copernican statement as a hypothesis, it is simpler than Tycho's and requires less movements to explain the phenomena". ${ }^{36}$ Tosca's anti-Copernican objections, rehearsed by Riva, are the traditional arguments of peripatetic physics made famous in Galileo's Dialogo: the birds that cannot find their nests, the heavy object falling from a height, the drag of the atmosphere, the cannonball shot eastward, and so on. ${ }^{37}$ Tosca mentions that he will leave aside other arguments set forth by Riccioli in his Almagestum novum, because they are too mathematical. ${ }^{38}$

As a conclusion, Riva treats cursorily on the issue of Scripture: he enumerates Biblical passages that support a geocentric view of the universe and comments that the Copernicans read them "metaphorice". ${ }^{39}$ As to the question of the condemnation of the system by the Inquisition, he contends that it is permitted to treat it hypothetically ("quod semper in hypothesi esse permissum"). ${ }^{40}$ Riva's position, advocating Copernicanism as a hypothesis with due regard to the literal reading of the Sacred Scripture was congruent with the removal from the Index of the general ban on Copernicanism. ${ }^{41}$ 


\section{Copernicanism and the Franciscans}

When in 1767 the Jesuits were expelled from Río de la Plata, the University of Córdoba was handed over to the Franciscans. ${ }^{42}$ The expulsion of the Society of Jesus from the Spanish domains in Iberian America has been interpreted as a consequence of the Bourbon reforms and the regalist policies of Charles III of Spain. ${ }^{43}$ The new spirit of Bourbon times involved an explicit turn toward Enlightenment or more properly, to the version of it that took root in the Iberian world. This large movement of ideas, usually called "Catholic Enlightenment," impinged on the learned culture of Río de la Plata, which ultimately had consequences for the treatment of Copernicanism - although it did not necessarily mean an instant conversion to it. ${ }^{44}$ The void left by the Jesuits was replaced by a conflicting field of forces in which Franciscans, the members of the secular clergy, and lay individuals identified with the reformist policies of the crown negotiated their political interests, competed for charges in the institutions of learning, and deployed their intellectual programs.

In this section, we will consider the teaching of the Copernican system by the Franciscans in Córdoba. This was a frequently discussed topic in the courses of physica and was also mentioned in the theses on the whole of philosophy defended by students between 1790 and 1810. The latter consisted of a limited number of propositions representative of the opinion of the teacher and published in booklets, as a rule in the Imprenta de los Niños Expósitos, the press of the public orphanage created in 1789 in Buenos Aires by Viceroy Vértiz. Before proceeding to analyze the individual authors, it seems necessary to look at the philosophical outlook framing the teaching of natural philosophy by the Franciscans in Spanish America.

In 1786, the Franciscan Commissar General for the Indies Manuel María Trujillo published a pastoral exhortation about the Plan of studies for the order. Trujillo's address was a manifesto for the new learning, which he saw fit to promote with the aim of refuting Rousseau, the Encyclopédie, d'Holbach's System of nature, and other "monsters of impiety" bent on "combating the Church and debunking Religion". 45 Trujillo extolled mathematicians and authors of handbooks and treatises of natural philosophy such as Pieter van Musschenbroek, the Franciscans Fortunato a Brixia (Fortunato da Brescia) and Lorenzo Altieri, the Oratorian Tosca, and the Minims Maignan and Seguens, while he harshly dismissed Peripatetic philosophy as a "false coin" and its defenders as the usurpers of the title of philosophers. ${ }^{46}$ After singing a paean to astronomy, a science that helps to elevate our thoughts to the Supreme Intelligence governing the world, Trujillo sends the reader into a heavenly voyage across the immense space where the orbs revolve in silent majesty. Although one of the wondrous sights of this cosmic excursion is Mercury, Venus, and Mars orbiting around the Sun the narrative seems to imply a geocentric universe. ${ }^{47}$ In what follows, we will see that the Franciscan teachers in Río de la Plata shared Trujillo's enthusiasm and also his limits, for while expressing an impulse for renovation, they frequently stopped short and remained within the bounds of orthodoxy.

Fr. Cayetano Rodríguez (1761-1823) was born in the province of Buenos Aires and joined the Franciscans in 1777. One year before he was ordained as a priest, he taught the course of Physica generalis (1782) in Córdoba, which was copied by one of the students. ${ }^{48}$ Previous commentators have underlined Fr. Cayetano's unregulated eclecticism, which on occasion led him to inconsistencies between traditional and modern natural philosophies. ${ }^{49} \mathrm{He}$ eventually moved to Buenos Aires, where he taught Logic, Metaphysics, and a course on Physica particularis, which has been preserved. ${ }^{50}$ This we will examine. 
Fr. Cayetano expounded in some detail the Ptolemaic, the Copernican and the Tychonic systems of the world. ${ }^{51} \mathrm{He}$ rejected the first on the grounds that it conformed neither to astronomy nor to physics. With respect to Tycho's system, he claimed that it contradicted neither physics nor astronomy and in consequence could be accepted "probabiliori ratione". 52 But in the end, Fr. Cayetano seems to have preferred the "oscillatory system" (more on this below) ${ }^{53}$ In the question on the Copernican system, he provides a brief description of the solar system, neatly reproduces an illustration from one of his sources (Joseph Ferrari's Philosophia peripatetica), and addresses head on the problem of the contradiction between Copernicus and the Bible, with due mention of Galileo's condemnation. ${ }^{54}$ Fr. Cayetano singles out Descartes, Gassendi, and Newton as champions of this system, refers to Edmond Purchot's argument who in good Cartesian fashion affirms that the Earth revolves around the Earth while not moving, and exactly as the Jesuit Riva had done he reproduces the quotation from Feijóo, also in Spanish, about all modern "physicists" being Copernicans. ${ }^{55}$

Treatment of Copernicanism in the manuscript is organized around two conclusions. The first is that the Copernican system is inconsistent with both the Sacred Scriptures and the truth and therefore can hardly be advocated ${ }^{56}$ Fr. Cayetano comments on a number of passages of the Bible conflictive with the immobility of the Sun (Eccles 1:5; Josh 10:13; Isa 38:8) and with the motion of the Earth (Eccles 1:4; Ps 95:10; Job 9:6). ${ }^{57}$ In each case he shows to his satisfaction that they should be read literally, since there is no indication that they ought to be interpreted metaphorically. He also lists several texts from the Church Fathers who affirm that the Biblical passages concerning the movement of the Sun and the immobility of our planet should be interpreted litteraliter ${ }^{58}$ For this material he drew on the handbooks of two fellow Franciscans, Fortunato a Brixia and Giuseppe Alberto Ferrari. ${ }^{59}$ Fortunato of Brescia was a favorite with Franciscans teachers in Río de la Plata. He conceded that the Copernican system could be sustained as a hypothesis, but unambiguously proclaimed that the Tychonic system should be preferred to its rivals. ${ }^{60}$ Ferrari, an Aristotelian with Scotist leanings, did not admit Copernicanism, not even "velut hypothesim". 61

Fr. Cayetano then embarks upon revisiting a series of eight arguments favoring the Copernican thesis, and provides anti-Copernican answers to each of them. The first three are concerned with the interpretation of the Bible and consist in the discussion of specific passages thereof. Others are astronomical (such as the alleged measures of stellar parallax by Flamsteed and Giovanni Domenico [Jean-Dominique] Cassini), physical (the vertical shooting of a cannonball) or methodological (the Inquisitors ignorant in matters astronomical). This material is taken mostly from Ferrari. ${ }^{62}$

Fr. Cayetano's second conclusio is that the Copernican system can be admitted only as a hypothesis. ${ }^{63}$ In order to sustain this statement, he rehearses a long list of anti-Copernican arguments, physical and astronomical, and provides a rejoinder to each of them. For these antiCopernican objections (as well as the corresponding answers) Fr. Cayetano drew in part upon Tosca. ${ }^{64}$ They feature the regular cast of birds, falling stones, and projectiles and also include new queries. If the Copernicans were right, then the regions of the Earth near the pole would move faster and the gravitational movement would slow down. Besides the omnipresent issue of the parallax, there are two anti-Copernican astronomical arguments: heliocentrism would be unable to explain the succession of day and night and the seasons, to which it should be added its inability to account for the retrograde movement of the planets (clearly, straw man propositions). 
In brief, Fr. Cayetano's scholastic approach to the Copernican system is twofold. On the one hand, he seeks to show as ineffectual a series of objections against the thesis, which he supports, that it contradicts the Bible and does not provides a real picture of the universe. On the other hand, he rejects a set of critiques against the thesis that it can be held hypothetically. As mentioned above, Fr. Cayetano favored the Tychonic system and even more the Systhema oscillationis or system of the pendulum. The latter assumed that the Earth was at the center of the Universe but moved with an oscillatory movement in the direction of the polar axis, completing a period in a year; this could explain the annual variation of solar declination. Its creator alleged that the Earth did not move since the range of oscillation was calculated in 300 leagues in each direction, with the result that at every instant, most of the mass of the planet would correspond to the center of the universe. This oscillatory system was the brainchild of Joseph Santiago de Casas, a Spanish dilettante who in 1758 proclaimed it to the world in the Relox universal de pendola [Universal pendulum clock], a book packed with letters from prelates and censors of all kinds extolling the orthodoxy of the author's theory. ${ }^{65}$ Casas was convinced that compared with the Copernican system, his idea excelled the latter "with a thousand advantages in goodness, in naturalness, in simplicity, in the soundness of its principles, in its easy comprehensibility, in the consonance with the sense of the Sacred Letters and with all the observations so far made in the world". ${ }^{66}$ I have not found traces of the circulation of Casas's book in learned circles, but it seems that one or more copies of it reached the Río de la Plata, where it was read with approval. Fr. Cayetano commended it for it contradicted neither the Sacred Scripture, nor physics, nor astronomy. ${ }^{67}$

Another Franciscan teacher, Fr. Elías del Carmen Pereyra (1760?-1825), born in the New World, was particularly active in the University of Córdoba during the decade of 1780; he also taught at the Franciscan Convent of that city. ${ }^{68}$ A manuscript with notes by a student of his course of Physica generalis, taught in 1784, has been preserved. ${ }^{69}$ More interesting for our purposes is a collection of theses on the whole of philosophy defended by students in public examinations: the Conclusiones ex universa philosophia $(1786,1790) .{ }^{70}$ Fr. Elías was an unprejudiced eclectic open to different currents and authors of natural philosophy-his only restriction is perhaps a qualified rejection of Newton. ${ }^{71}$

Ostensibly, Fr. Elías adhered to the Copernican system on the grounds that it saved both the astronomical and the physical phenomena, whereas, in his view, the Tychonic arrangement, only explained the former. As to the conflictive passages of the Bible, he affirmed that they should be explained "in metaphorical sense and accommodated to the uneducated". ${ }^{72}$ Despite this auspicious opening, in the end the Franciscan teacher denied that the Copernican system could be defended as a thesis, for its supporters had not been able to provide a demonstration of it. James Bradley's demonstration, contends Fr. Elías, was so defective that it was "not even probable". (He is of course referring to Bradley's discovery of the aberration of light, usually assumed as a demonstration of the movement of the Earth. ${ }^{73}$ ) The Franciscan takes opportunity to censure Juan Francisco de Castro, who in his work Dios y la naturaleza [God and Nature] considered some kind of heliocentric system as certain, coming ahead of the judgement of the Church. Castro was a reputed enlightened priest from Galicia (Spain), who had published an encyclopedic work in ten volumes on the religions and cults of pre-Christian peoples, the first of which is dedicated to natural theology. ${ }^{74}$ In it, he explicitly claims that the Sun is an immense luminous globe established in an "immobile center" around which the planets revolve. ${ }^{75}$

Despite his declaration in favor of Copernicanism taken as a hypothesis, Fr. Elías rebuffed the Copernican explanation of the winds in the Torrid Zone as a result of the movement of the Earth and proposed as an alternative account the movement of the Sun. ${ }^{76}$ This kind of 
inconsistency reveals the limits of his grasp of the problems involved in the momentous issue of the system of the world.

In 1792, another Franciscan teacher, Fr. Anastasio Mariano Suárez, put together a group of theses to be defended by students in Córdoba: Asserta ex universa philosophia. ${ }^{77}$ This is a very brief work, but enough to see that Fr. Atanasio's position with respect to several important doctrines coincide with those of Fr. Elías del Carmen. He supported the Tychonic system, which should be preferred to all the rest, but granted that the Copernican system could be defended "sub hypothesi... habita reverentia Romanae Ecclesiae". ${ }^{78}$ Immediately after this brief statement, Fr. Anastasio declares that the Earth is unmoving in the center of the universe.

In July 1803, one of the students of the Franciscan Juan Fernández defended a set of theological theses at the Franciscan Convent of the Recoleta (Buenos Aires), which were published as Conclusiones...ex praecipuis Sacrae Theologiae tractatibus depromptae. ${ }^{79}$ The theses follow the traditional order of theological treatises and the chapters on creation include material on natural philosophy and cosmology ${ }^{80}$ The author leaves aside the Ptolemaic system for it agrees neither with astronomy nor with physics. He admits the Copernican system but only if held hypothetically. Although claiming that the systhema oscillationis can be defended as a thesis to the extent that it does not contradict the Sacred Scripture, Fr. Fernández prefers the Tychonic system for it is consonant with astronomy, physics, and the Bible. ${ }^{81}$

Summing up, neither of these authors was inclined to support the Ptolemaic system. They inclined themselves for Tycho's system or, as was the case with Fr. Cayetano, for the Systhema oscillationis, also looked with benevolence by Fr. Juan Fernández. Although they admitted the Copernican system as a hypothesis, they underlined that it was not supported by the astronomical evidence (Fr. Elías) or hastened to affirm that in the end, the Earth did not move (Fr. Anastasio). The positions in each case are not always entirely consistent. The collections of theses consisted of short stereotyped statements which could only with difficulty spell out the intricacies of the question. The authors depended on their sources, usually handbooks of natural philosophy. As evidenced by their enthusiasm for the system of the pendulum, they were not always in a position to evaluate soundly the quality of their material. All of them moved within the boundaries of orthodoxy and took seriously the question of the contradiction between the Copernican view and the texts of the Bible.

\section{The secular clergy in Buenos Aires}

Soon after taking office as governor of Buenos Aires in 1772, Juan José de Vértiz-a prototype of the enlightened colonial functionary-prompted the Junta de Temporalidades (a unit in charge of administrating the patrimony that had belonged to the Society of Jesus) to create the Real Colegio de San Carlos, with chairs of grammar (Latin) and philosophy. Eventually another chair of philosophy and two of theology were added. ${ }^{82}$ In November 1783 , Vértiz, who was by then viceroy of Río de la Plata, founded the Real Convictorio Carolino, an internship for students that attended the courses in San Carlos, which were in charge of secular priests.

The Spanish priest Melchor Fernández (1762?-after 1819), who taught philosophy in San Carlos between 1789 and 1792, prepared a group of 128 Theses de universa philosophia, which were defended in September $1792 .{ }^{83}$ Ninety-three of these theses deal with natural philosophy. As most of his colleagues, Father Fernández was an eclectic engaged with the problems presented by grafting the new science into a traditional metaphysics. He subscribes to the 
Newtonian theory of colors, dismisses substantial and accidental forms, and follows Descartes in his rejection of a spiritual soul in animals and in the account of the seven rules of collision. He also considers an impiety the affirmation that God could not create a vacuum and affirms that the cause of gravity is "an immediate operation of God". Melchor Fernández decidedly preferred the Copernican system to the others (which he does not even mention), with the proviso that it be taken as a hypothesis. He claimed that "the determination [determinatio] of the Supreme Artificer is the motive cause of the heavens and the planets". ${ }^{84}$

José Valentín Gómez (1774-1839), also a secular priest, taught philosophy at San Carlos between 1799 and 1801. In 1802, he had three of his students defend a set of Conclusiones ex universa philosophia as the culmination of the whole course. ${ }^{85}$ Furlong has acclaimed Gómez as the most consistent and profound teacher of philosophy in Colegio de San Carlos and the acutest thinker in colonial Río de la Plata. ${ }^{86}$ As far as the Conclusiones are concerned, this judgment seems overgenerous. In regard to natural philosophy and when compared to analogous works, Valentín Gómez's Conclusiones do not stand out as particularly originalalthough it should be conceded that the range of authors mentioned by him is slightly larger than in his colleagues. Gómez's students declared that they subscribed "libentissime" to the Copernican hypothesis for it explained the astronomical as well as the physical phenomena. As concerns the Tychonic system, Father Gómez thought that Tycho explained the physical, but not the astronomical phenomena, thus running into "insurmountable difficulties". ${ }^{87}$ Gómez seems to have followed in the steps of Fr. Elías in his interpretation of the geocentric scriptural passages as metaphorical and adapted to the unlearned, and also in his dismissal of Bradley's proof and alarm at Castro's heliocentric intimations. ${ }^{88}$

Summing up, the secular priests at San Carlos seem to have adopted a slightly more favorable stance toward the Copernican system than their Franciscan colleagues - this is certainly true of Melchor Fernández. Two factors could have played a role. Firstly, their courses were taught around a decade later. In the second place, as we will see below, the coastal city of Buenos Aires was rather more open to the sea winds of novelties than the traditional university of Córdoba.

\section{The Nautical Academy}

Certainly a rather different setting from that of college and university education was the Nautical Academy in Buenos Aires. Founded in 1799 by Manuel Belgrano, secretary general of the Consulado (something in between a chamber of commerce and a commercial court), this was one of the professional schools created in Buenos Aires in the years around the turn of the century in the atmosphere of late colonial reform inspired by the Bourbons. ${ }^{89}$ The kind of knowledge transmitted in these schools was useful knowledge, the kind that could be used for the advancement of commerce and the trades. These were the only places in the whole Viceroyalty where youngsters could be taught mathematics and astronomy, extolled for their practical value as the basis of economical advance and an emblem of progress.

The Nautical Academy prospered under the conduction of Pedro Cerviño, an enlightened military engineer native of Galicia (Spain), probably educated in the Academy of Mathematics of Barcelona and with an extensive activity as cartographer, topographer, and civil engineer in Río de la Plata. Cerviño arrived in Buenos Aires as an expert in the commission for the demarcation of limits between Spanish and Portuguese territories as a result of the Treatise of San Ildefonso (1777). ${ }^{90}$ 
The school for pilots of the consulado-closed in 1806 by the monarch since it compromised the interests of the neighbor port of Montevideo-had an ambitious plan of studies, which included a fair amount of mathematics and physics. Cerviño was a defender of Newtonian science and his view of the Copernican system contrasts with those of the teachers of natural philosophy. In this respect, the situation in Buenos Aires reflected that in Spain. Although during the Bourbon era there was a degree of renovation in the universities of the metropolis, the new science was fundamentally cultivated in naval and military academies and in schools of medicine. ${ }^{91}$

The lecture with which in January 1806 Cerviño opened a three-day period of exams of the Nautical School was delivered to an audience which included Viceroy Sobremonte, the authorities of the Consulado and other local worthies. Cerviño opens his éloge of the science of astronomy with a reference to the Egyptians' knowledge of the heavens and concludes in a triumphal note with Hershel's discovery of Uranus in 1781. As the highlights of Greek astronomy he mentions Aristarchus, Eratosthenes, and Hipparchus; he understandably omits Ptolemy and extols "the Arabs" and the medieval Castilian king Alfonso X. His rendition of Copernicus' triumph is worth quoting:

Finally Copernicus appeared on the scene and with a spirit as strong as his ingenuity stumbled upon the beliefs of all the learned men of his time [and] tried to persuade them that everything is an illusion, that the Sun and the stars are at rest and what is moving is the mass of the globe we inhabit. ${ }^{92}$

In Cerviño's discourse the names of Galileo, Kepler, and Huygens precede the invocation of the "immortal Newton," whose inverse square law the orator takes a moment to describe.

A long paragraph of the short lecture is devoted to an enumeration of the many themes Cerviño had been teaching since five years ago, from algebra to "infinitesimal calculus... which will consecrate to immortality the names of Newton and Leibniz". ${ }^{93}$ Then come dynamics and hydrodynamics, and crowning his ambitious scheme, "astronomy, which elevates the human being above himself" and "the physical theory of celestial bodies and the reciprocal forces with which the planets alter their movements and oblige the comets to alter the period of their revolutions". ${ }^{94}$

In his project and plan of studies for the Nautical Academy, Cerviño recommended the use of Étienne Bézout's Cours de mathématiques. ${ }^{95}$ Also, the consulado had taken the opportunity that the Catalan mathematician Benito Bails was preparing a new edition of his three-volume Principios de matemáticas and bough 300 sets of the treatise, which arrived in Buenos Aires in $1805 .{ }^{96}$ The prologue of the astronomy section includes several pages translated from Bailly's Histoire de l'astronomie, which could have inspired Cerviño's discourse (although there are no literary parallels between them) ${ }^{97}$ Bails reproduced this prologue in the volume devoted to astronomy of his ten-volume Elementos de matemáticas. ${ }^{98}$ At the time of the creation of the Public Library in Buenos Aires (1810), Manuel Belgrano donated to it three volumes of Bails's Elementos, among which was the one on astronomy. ${ }^{99}$ The prizes given to the best students of the Academy for the year 1802 consisted of a sextant, a case of compasses, and a complete set of Bails's books. ${ }^{100}$

Bails had had an entirely French education and his Elementos were strongly dependent on Bézout's Cours. ${ }^{101}$ Between 1791 and 1793, he had been in prison because of accusations by the Inquisition of liberalism and materialism. ${ }^{102}$ In his Principios, he claimed that the system 
of Copernicus is the true one ("el verdadero"). ${ }^{103}$ The objections derived from the texts of the Sacred Scripture he dismisses on the grounds of the principle of accommodation and claims that the decree of the Inquisition of 5 March 1616 did not qualified Copernicus book as heretic; besides, he argues, Copernicanism has since long been taught in Rome as a hypothesis "and the same are called to do those who prefer to be on the safe". ${ }^{104}$ In the Elementos Bails was more guarded. There he says that "many enlightened European nations take Copernicus' system for the true [system of the world]". In ironic condescension to the censors, he adds that he will just expose the reasons of the supporters of the system in order to show how justified is "the authority of men [sic] in limiting the excesses of human reason". ${ }^{105}$

\section{Epilogue}

It has been claimed that around 1774 the prohibition of Copernicanism began to relax in Spain, but this does not seem to apply to clerics in charge of teaching natural philosophy in Río de la Plata. ${ }^{106}$ We find the first documented statement in support of the Copernican system in a public lecture by a naval engineer whose profile and career embodied the ideals of Bourbon enlightenment. In his well-crafted oratory piece Cerviño sang the praise of Newtonian celestial mechanics in an effort to rhetorically legitimize his educational program of providing pilots with an extensive and sound coverage of the basic exact sciences. The Consulate, also a product of the Bourbon atmosphere of reform and rationalization of the resources of empire, was a strong institution in a port city run by a merchant elite. ${ }^{107}$ Proof of this backing was the large amount of money invested in the buying of a fair number of copies of Bails's Principios.

It is no always a straightforward matter to assess the opinions of the clerics who taught the system of the world. The Jesuit Benito Riva showed himself as a supporter of the Copernican system considered as a hypothesis. He does not pay particular attention to Tycho's system and devotes almost the totality of his lecture to set Copernicus in the best possible favorable light, through a careful handling of his sources.

The Franciscans were in the whole more cautious, always emphasizing that Copernicanism should be taught hypothetically. Fr. Cayetano's long-winded arguments and final uneasiness contrast with Riva's focused and resolved address of the question. In their theses, the other Franciscan teachers also trod with caution. Was this a conventional gesture of acquiescence to avoid the troubles of contradicting the official position of the Church in this matter or was it a genuine assent of mind? This question is hard to answer, but it is unlikely that these authors could be charged of excessive boldness.

Except for Cerviño, all the authors considered were clerics. His training in astronomical matters was limited to the course of natural philosophy they were in charge of teaching and they depended for that on the available handbooks and books of reference. For example, the technical level of Giovanni Battista Riccioli's Almagestum novum (Bologna, 1651, 2 vols.) was above most if not all the teachers; it is evident that it was quoted secondhand. ${ }^{108}$ Considering the limitations of their own background, they did rather fine. But in the end, the shortcomings showed, as for example, in their reception of the system of oscillation. Río de la Plata was not the brightest of settings for the teaching of natural philosophy. The University of Córdoba toiled under its traumatic past and its conflictive present (the expulsion of the Jesuits in 1767 and the hasty transfer of government to the Franciscans, who had to operate under the constant harassment of the secular clergy). In Buenos Aires, a city without university, the position of professor of philosophy in San Carlos was considered as a stepping stone in an ecclesiastical 
or political career (perhaps both). Fr. Cayetano and Valentín Gómez played distinguished roles in the political events that followed the emancipation from Spain of the Provinces of Río de la Plata. ${ }^{109}$

The reception of Copernicus in Río de la Plata was a protracted and erratic process. New ideas should be sought in settings like the Nautical Academy-a product of enlightened reform. But we have also seen that the teaching in Córdoba during the Jesuit period was clearly more favorable to the Copernican position than in later Franciscan times and the same could be said of the secular clergy teaching in Buenos Aires.

Acknowledgement: I am grateful to Prof. Ignazio Angelelli (University of Texas at Austin) for his reading of an earlier version of the manuscript and also to the referees and editor of the $J H A$, whose useful remarks helped to improve the paper. Lic. Susana Brandáriz gently facilitated the consult of the manuscripts held in the FACJA. 
${ }^{1}$ Philip Keenan, “Astronomy in the Viceroyalty of Peru,” in A. Lafuente, A. Elena and M. L. Ortega (eds.), Mundialización de la ciencia y cultura nacional (Madrid: Universidad Autónoma-Doce Calles, 1993), pp. 297305.

${ }^{2}$ Luis C. Arboleda and Diana Soto-Arango, "The Theories of Copernicus and Newton in the Viceroyship of Nueva Granada and the Audiencia de Caracas in the $18^{\text {th }}$ Century," in Mordechai Feingold and Víctor NavarroBrotóns (eds.), Universities and Science in the Early Modern Period (Dordrecht: Springer, 2006), pp. 289-311; Ekkart Keeding, "Las ciencias naturales en la Antigua Audiencia de Quito: el sistema copernicano y las leyes newtonianas," Boletín de la Academia Nacional de Historia [Quito], 57 (122), 1973, pp. 43-67.

${ }^{3}$ For the participation of the clergy in the scientific aspects of Enlightenment in Spain and its domains, see David Goodman, "Science and the Clergy in the Spanish Enlightenment," History of Science, 21, 1983, pp. 111140 and Víctor Navarro, "Tradition and Scientific Change in Early Modern Spain: the Role of the Jesuits," in Mordechai Feingold (ed.), Jesuit Science and the Republic of Letters (Cambridge, Mass.: MIT Press, 2003), pp. 331-387.

${ }^{4}$ Maurice A. Finocchiaro, Defending Copernicus and Galileo. Critical Reasoning in the Two Affairs (Dordrecht: Springer, 2010), p. 183.

${ }^{5}$ Miguel de Asúa, La ciencia de Mayo. La cultura científica en el Río de la Plata, 1800-1820 (Buenos Aires: Fondo de Cultura Económica, 2010), pp. 93-116.

${ }^{6}$ Ernesto Maeder, "Libros, bibliotecas, control de lecturas e imprentas rioplatenses en los siglos XVI a XVIII," Teología, 77, 2001, pp. 5-24.

${ }^{7}$ For a history of the university in the Jesuit period, see Juan Mamerto Garro, Bosquejo histórico de la Universidad de Córdoba (Buenos Aires: M. Biedma, 1882), pp. 11-117 and Joaquin Gracia S.J., Los jesuitas en Córdoba (Buenos Aires: Espasa-Calpe Argentina, 1940), chaps. 17, 18, 25, 26, and 38; consult also Carlos A. Page, El Colegio Máximo de Córdoba (Argentina) según las Cartas Anuas de la Compañía de Jesús (Córdoba: BR Copias, 2004).

${ }^{8}$ Guillermo Furlong S.J., Matemáticos argentinos durante la dominación hispánica (Buenos Aires: Huarpes, 1945), pp. 86-7. For Quiroga's life and activities in Río de la Plata, see Guillermo Furlong S.J., El Padre José Quiroga (Buenos Aires: Peuser and Facultad de Filosofía y Letras, 1930). Domingo Muriel S.J., who renovated the teaching of philosophy in Córdoba in the years 1749-1751 taught the students a summary of mathematics taken from the works of Claude François Millier Dechale S.J. See Guillermo Furlong S.J., Nacimiento y desarrollo de la filosofía en el Río de la Plata, 1536-1810 (Buenos Aires: Kraft, 1952), p. 179. The lack of formal mathematical teaching implies that the University of Córdoba was not a teaching setting where discussion about the role of mathematics in the Jesuit curriculum could be profitably discussed, such as has been studied in Peter Dear, "Jesuit mathematical science and the reconstitution of experience in the early seventeenth century," Studies in History and Philosophy of Science Part A 18, 1987, 133-75; Steven J. Harris, "Les chaires de mathématiques," in L. Giard (ed.), Les Jésuites à la Renaissance: Système éducatif et production du savoir (Paris: P.U.F., 1995), pp. 239-61; Ugo Baldini, “The Academy of Mathematics of the Collegio Romano from 1553 to 1612," in Mordechai Feingold (ed.), Jesuit Science and the Republic of Letters (Ref. 3), pp. 47-98; or the more recent Renée J. Raphael, "Copernicanism in the Classroom: Jesuit Natural Philosophy and Mathematics after 1633," Journal of the History of Astronomy, 46, 2015, pp. 419-40.

${ }^{9}$ For bibliography on Rubio, see L. Martínez Gómez S.J., s.v. "Rubio, Antonio," in Charles E. O’Neill S.J. and Joaquín M. Domínguez S.J. (eds.), Diccionario Histórico de la Compañía de Jesús (Roma: IHSI, Madrid: Universidad Pontificia Comillas, 2001, 4 vols.).

${ }^{10}$ François de Dainville S.J., L'éducation des jésuites (XVI -XVIII siècles) (Paris: Minuit, 1978), pp. 375-6.

${ }^{11}$ Antonio Astrain S.J., Historia de la Compañía de Jesús en la Asistencia de España (Madrid: Administración de Razón y Fe, 1925), vol. 7, pp. 22-3. No representative of the Rio de la Plata was present in that congregation. ${ }^{12}$ Furlong, Nacimiento y desarrollo de la filosofía (Ref. 8), pp. 167-70.

${ }^{13}$ Marcus Hellyer, Catholic Physics. Jesuit Natural Philosophy in Early Modern Germany (Notre Dame: Notre Dame University Press, 2005), pp. 178 and 191-2; Astrain, Historia de la Compañía de Jesús (Ref. 11), p. 26.

${ }^{14}$ Alberto Fraschini (ed.), Index Librorum Bibliothecae Collegii Maximi Cordubensis Societatis Iesu (Córdoba: Universidad Nacional de Córdoba, 2005, 2 vols.), vol. 1, pp. 367, 219, and 269.

${ }^{15}$ Fraschini, Index Librorum (Ref. 14), pp. 303, 353, and 250. A provisory list of books transferred from all Jesuit houses to the the Fondo Antiguo de la Compañía de Jesús en la Argentina, in Buenos Aires (from now on mentioned as FACJA) mentions Gassendi's Miscellanea (Lyon, 1658), vol. 5 of his complete works.

${ }^{16}$ Fraschini, Index Librorum (Ref. 14), vol. 1, p. 303. A copy of Ferguson's Astronomy is held in FACJA.

${ }^{17}$ Celina Lértora Mendoza, "Los estudios superiores rioplatenses y su función en la dinámica cultural," in José L. Peset (ed.), Ciencia, vida y espacio en Iberoamérica (Madrid, CSIC, 1989, 3 vols.), vol. 1, p. 398; idem, "Introducción de las teorías newtonianas en el Río de la Plata," in Lafuente et al. (eds.), Mundialización de la ciencia y cultura nacional (Ref. 1), pp. 307-23; idem, "Nollet y la difusión de Newton en el Río de la Plata," in Celina Lértora Mendoza, Efthymios Nicolaïdis, and Jan Vandersmissen (eds.), The Spread of the Scientific 
Revolution in the European Periphery (Turnhout, Brepols, 2000), pp. 123-36; Carlos D. Galles, "La enseñanza de las ideas newtonianas sobre la luz en la Universidad de Córdoba," in Lértora et al., The Spread of the Scientific Revolution in the European Periphery (Ref. 17), pp. 110-22.

${ }^{18}$ Miguel de Asúa, "Acerca de la biografía, obra y actividad médica de Thomas Falkner S. J. (1707-1748)," Stromata, 62, 2006, pp. 227-54.

${ }^{19}$ Suárez translated the Theorica verdadeira das marés (London, 1737), a book on the Newtonian theory of the tides by the Portuguese Sephardi physician exiled in England Jacob de Castro Sarmento, but the manuscript is lost. Annua 1750, Fondo Bib. Nac. 8156, Archivo General de la Nación (Argentina). For Suárez, see Miguel de Asúa, Science in the Vanished Arcadia. Knowledge of Nature in the Jeuits Missions of Paraguay and Río de la Plata (Leiden: Brill, 2014), pp. 222-53.

${ }^{20}$ Martín Morales, La Librería Grande. El Fondo Antiguo de la Compañía de Jesús en la Argentina (Rome: IHSI, 2002), pp. 94-101.

${ }^{21}$ Fraschini, Index (Ref. 14), vol. 1, pp. 193, 194, 310, and 384.

${ }^{22}$ Fraschini, Index (Ref. 14), vol. 1, pp. 65 and 61.

${ }^{23}$ Catalogue in FACJA.

${ }^{24}$ For Riva and his course, see Furlong, Nacimiento y desarrollo (Ref. 8), pp. 187-92. A transcription of the table of contents of the manuscript can be seen in Celina Lértora Mendoza, La enseñanza de la filosofía en tiempos de la colonia. Análisis de cursos manuscritos (Buenos Aires: FECIC, 1979), pp. 215-40.

${ }^{25}$ Furlong, Nacimiento y desarrollo (Ref. 8), p. 187.

${ }^{26}$ Furlong, Nacimiento y desarrollo (Ref. 8), p. 188.

${ }^{27}$ Benito Riva, [Cursus physicae], De mundo et caelo, ff. 306v-319r, FACJA.

${ }^{28}$ Bernardo Feijóo, Cartas eruditas y curiosas (Madrid: Joachin Ibarra, 1770, 5 vols.), vol. 3, pp. 199-212 (letter 20) and vol. 4, pp. 258-71 (letter 21).

${ }^{29}$ See Antonio Lafuente y Manuel A. Sellés García, "La física en Feijóo: tradición y renovación,” in Santiago Garma Pons (ed.), El científico español ante su historia: la ciencia en España entre 1750-1850: I Congreso de la Sociedad Española de Historia de las Ciencias (Madrid: Diputación Provincial de Madrid, 1980), pp. 169-88; Antonio T. Reguera Rodríguez, "Newton y Feijóo. Un episodio en la difusión de las ideas científicas,"

Contextos, 19-20, 2001-2002, pp. 283-344.

${ }^{30}$ Feijóo, Cartas eruditas (Ref. 28), vol. 3, p. 210.

${ }^{31}$ Riva, Cursus (Ref. 27), f. 310v. Cf. Feijóo, Cartas eruditas (Ref. 28), vol. 4, p. 262 and Mémoires pour

l'Histoire des Sciences et des Beaux-Arts [Journal de Trévoux] 1746, April, pp. 907-911.

${ }^{32}$ Riva, Cursus (Ref. 27), f. 310v. Cf. Feijóo, Cartas eruditas (Ref. 28), vol. 4, p. 263.

${ }^{33}$ Riva, Cursus (Ref. 27), ff. 311r-311v. Cf. Feijóo, Cartas eruditas (Ref. 28), vol. 3, p. 208.

${ }^{34}$ Riva, Cursus (Ref. 27), Liber I, disputatio $1^{\mathrm{a}}$, sectio $6^{\mathrm{a}}$, f. $13 \mathrm{r}$. This is one of several arguments against gravity. Riva's discussion on Newton's natural philosophy ocuppies ff. $10 \mathrm{r}-15 \mathrm{v}$ of the manuscript.

35 Tomás Vicente Tosca, Compendium philosophicum (Valencia: Viuda de Jerónimo Conejo, 1754, 6 vols.), vol. 5, pp. 89-119. On Tosca, see See Navarro, "Tradition and Scientific Change” (Ref. 3), pp. 355-7.

${ }^{36}$ Tosca, Compendium (Ref. 35), vol. 5, pp. 118-19.

${ }^{37}$ Riva, Cursus (Ref. 27), ff. 311v-313v. Cf. Tosca, Compendium (Ref. 35), vol. 5, pp. 106-117. For a general discussion on these arguments, see Edward Grant, "In Defense of the Earth's Centrality and Immobility:

Scholastic Reaction to Copernicanism in the Seventeenth Century," Transactions of the American Philosophical Society, New Series, 74 (4), 1984, pp. 1-69.

${ }^{38}$ Riccioli had considered 39 arguments against the movement of the Earth, see idem, Almagestum novum...Pars posterior tomi primi (Bologna: ex typographia haeredis Victorii Benatii, 1651), pp. 408-77. See Grant, "In Defense of the Earth's Centrality" (Ref. 37); Alfredo Dinis, "Giovanni Battista Riccioli and the Science of his Time," in Feingold, Jesuit Science and the Republic of Letters (Ref. 3), pp. 192-224; Christopher M. Graney, "Science Rather than God: Riccioli's Review of the Case for and against the Copernican Hypothesis," Journal for the History of Astronomy, 43, 2012, pp. 215-26; idem, Setting Aside All Authority. Giovanni Battista Riccioli and the Science against Copernicus in the Age of Galileo (Notre Dame: University of Notre Dame Press, 2015).

${ }^{39}$ Riva, Cursus (Ref. 27), f. 314r.

${ }^{40}$ Riva, Cursus (Ref. 27), ff. 314v-315r.

${ }^{41}$ It was also on a par with contemporary Jesuit teaching in German speaking lands, see Hellyer, Catholic Physics (Ref. 13), pp. 233-6.

42 Actually, according to the disposition of the crown, it should have been transferred to the secular clergy, but governor Bucarelli took into account that most of the secular priests had studied under the Jesuits on account of which they were considered not reliable for the authorities. See Garro, Bosquejo histórico (Ref. 7), pp. 27-9.

${ }^{43}$ Magnus Mörner, "The Expulsion of the Jesuits from Spain and Spanish America in 1767 in Light of

Eighteenth-Century Regalism," The Americas 23, 1966, pp. 156-64. 
${ }^{44}$ For Catholic Enlightenment in Spain and its colonies, see Andrea J. Smidt, “'Luces por la Fe': The Cause of Catholic Enlightenment in 18th-Century Spain," In Ulrich L. Lehner and Michael O'Neill Printy (eds.), A Companion to the Catholic Enlightenment in Europe (Leiden: Brill, 2010), pp. 403-52. For the situation in Río de la Plata, see José Carlos Chiaramonte, La ilustración en el Río de la Plata, Cultura eclesiástica y cultura laica durante el Virrreinato (Buenos Aires: Sudamericana, 2007).

${ }^{45}$ Fr. Manuel María Truxillo OFM, Exhortación Pastoral (Madrid: Viuda de Ibarra, 1786), p. 158.

${ }^{46}$ Truxillo, Exhortación (Ref. 45), pp. 170 and 186.

${ }^{47}$ Truxillo, Exhortación (Ref. 45), p. 174.

${ }^{48}$ Fr. Cayetano Rodríguez, Tertia Philosophiae Pars Nimirum Physica...1782. Codex in FACJA.

${ }^{49}$ Furlong, Nacimiento y desarrollo (Ref. 8), pp. 245-56; Lértora Mendoza, La enseñanza de la filosofía (Ref. 24), pp. 241-58.

${ }^{50}$ Fr. Cayetano Rodríguez, Secunda Phisicae Pars, seu Phisica Particularis (undated; probably 1782-1783). I have used the manuscript held at the FACJA, which is not paginated. It contains two books: De mundo ac de precipuis mundi sistematibus and De caelo et corporibus caelestibus. For the manuscripts of Fr. Cayetano's course, see Furlong, Matemáticos argentinos (Ref. 6), pp. 183-4 and Fray Pacifico Otero OFM, Estudio biográfico sobre Fray Cayetano Rodríguez (Córdoba: La Velocidad, 1899), pp. 13 and 19.

${ }^{51}$ Rodríguez, Secunda physice pars (Ref. 50), Liber I, quaestiones 6, 7, and 8 respectively.

${ }^{52}$ Rodríguez, Secunda physice pars (Ref. 50), Liber I, quaestio 8 ("Quid dicendum sit de sisthemate tichonico").

${ }^{53}$ Rodríguez, Secunda physice pars (Ref. 50), Liber I, quaestio 9.

${ }^{54}$ Joseph Ferrari, Philosophia peripatetica adversus veteres et recentiores praesertim philosophos firmioribus propugnata rationibus Ioannis Dunsii Scotii...editio secunda (Venice: Thomas Bettinelli, 1754, 3 vols.), vol. 3, tabula III.

${ }^{55}$ Edmund Purchot, Institutiones philosophicae (Padua: Typis Seminarii, 1751, 5 vols.) vol. 3, p. 28.

56 "Copernicanum systhema adversatur apertissimis divinarum Scripturarum sententiis, nec veritati consentaneum est, nec ut tale propugnari potest" (Cayetano Rodríguez, Secunda physice pars [Ref. 50], Liber I, quaestio 7).

${ }^{57}$ References correspond to the Vulgate version of the Bible.

${ }^{58}$ Augustine, De civitate Dei book 21, chap. 8; John Chrysostom, Homilies on Hebrews, homily 27;

Hieronymus, Commentary on Ecclesiastes, chap. 1.

${ }^{59}$ Fortunatus a Brixia [Fortunato da Brescia], Philosophia sensumm mechanica. Tomus tertio. Physices particularis. Pars prima. De caelo et astris (Venice: Typographia Remondiniana, 1756), pp. 140-6; Ferrari, Philosophia peripatetica (Ref. 54), vol. 3, pp. 34-40.

${ }^{60}$ Brixia, Philosophia sensuum mechanica (Ref. 59), pp. 161-2 and 173.

${ }^{61}$ Ferrari, Philosophia peripatetica (Ref. 54), vol. 3, p. 41.

${ }^{62}$ Ferrari, Philosophia peripatetica (Ref. 54), vol. 3, pp. 42-5. For Flamsteed's measure of stellar parallax (and reference to Cassini's) see M. E. Williams, "Flamsteed's alleges measurement of annual parallax," Journal of the History of Astronomy, 10, 1979, 102-116.

63 "In systhema copernicano si admittatur omnia phaenomena coelestia recte explicantur, unde potest ut hypothesis propugnari" (Cayetano Rodríguez, Secunda physice pars [Ref. 63], Liber I, quaestio 7).

${ }^{64}$ They are roughly the same as those used by the Jesuit Riva. Tosca, Compendium (Ref. 35), vol. 5, pp. 106117.

${ }^{65}$ Joseph Santiago de Casas, Relox universal de pendola y en él nueva idea de la estructura del universo. Se declara la colocación del globo terráqueo, y su movimiento de oscilación en el centro del universo y el movimiento del Sol alrededor del globo en círculo perfecto, sin declinación (Madrid: Herederos de la Viuda de Juan García Infanzón, 1758). This book has been mentioned in Juan Vernet, "Copernicus in Spain," in Jerzy Dobrzycki (ed.), The Reception of Copernicus' Heliocentric Theory. Proceedings of a Symposium Organized by the Nicolas Copernicus Committee of the International Union of the History and Philosophy of Science. Torún, Poland, 1973 (Dordrecht: Springer Science, 1972), pp. 271-91, in p. 281.

${ }^{66}$ Casas, Relox universal (Ref. 65), p. 190.

67 “Admittendum est systhema oscillationis seu pendulus est minime disconformis Sacrae Scripturae, astronomiae et Physicae legibus" (Rodríguez, Secunda physice pars [Ref. 50], Liber I, quaestio 9).

${ }^{68}$ Juan C. Zuretti, "Fray Elías del Carmen Pereyra, profesor de la Universidad de Córdoba," Itinerarium [Buenos Aires], 11, 1947, 353-71; Furlong, Nacimiento y desarrollo (Ref. 8), pp. 257-9.

${ }^{69}$ It has been edited in Spanish translation, see Elías del Carmen Pereyra, Física, translated by Juan Chiabra, in Universidad de La Plata, La enseñanza de la filosofía en la época colonial (Buenos Aires: Coni, 1911, Biblioteca Centenaria, 2), pp. 173-435.

${ }^{70}$ The Conclusiones (Buenos Aires: apud Typographiam Regiam Parvulorum orphanorum, 1786) were defended in Córdoba by the Chilean Gabino Sierralta and others in 1786. They were also defended in 1790 by other Chilean students, Francisco Javier Martínez de Aldunate and his brother Francisco Genaro. The latter edition 
has been published in Spanish translation, see Enrique Paz Martínez, "Una tesis de filosofía del siglo XVIII en la Universidad de Córdoba," Revista de la Universidad de Córdoba, 6 (1), 1919, pp. 228-86, in pp. 255-86. For the editions of Fr. Elías's works see Zuretti, "Fray Elías del Carmen Pereyra” (Ref. 68), pp. 259-60 and Furlong, Nacimiento y desarrollo (Ref. 8), pp. 259-60.

${ }^{71}$ This has already been pointed out in Lértora, La enseñanza de la filosofía (Ref. 24), p. 178. Furlong considered Pereyra "the most original of the Franciscan thinkers" of the period, see Furlong, Nacimiento $y$ desarrollo (Ref. 8), p. 259.

${ }^{72}$ Martínez Paz, "Una tesis de filosofía” (Ref. 70), p. 277.

${ }^{73}$ See, for example, James Bradley, Edmond Halley and George Sarton, "Discovery of the Aberration of Light," Isis, 16, 1931, pp. 233-65.

${ }^{74}$ Juan Francisco de Castro, Dios y la naturaleza. Compendio histórico natural, y político del Universo, en que se demuestra la existencia de Dios y se refiere la Historia Natural, y Civil, la Religión, leyes y costumbres de las Naciones antiguas y modernas más conocidas del Orbe (Madrid: Ibarra, 1780-1791, 10 vols.).

${ }^{75}$ Castro, Dios y la naturaleza (Ref. 74), vol. 1, p. 34.

${ }^{76}$ Martínez Paz, "Una tesis de filosofía" (Ref. 70), p. 283.

${ }^{77}$ Fr. Anastasio Mariano Suárez, Asserta ex universa philosophia (Buenos Aires: Typographiam Regiam Parvulorum orphanorum, 1792). For a comment on these theses, see Furlong, Nacimiento y desarrollo (Ref. 8), pp. 277-81.

78 Anastasio Suárez, Asserta ex universa philosophia (Ref. 77), p. 7.

${ }^{79}$ Fr. Juan Fernández, Conclusiones publico-historico-dogmatico-scholastico-phisico-theologicae ex praecipuis Sacrae Theologiae tractatibus depromptae (Buenos Aires: Apud Typographiam Regiam Parvulorum Orphanorum, 1803). The student was Manuel Buenaventura Villegas. For a brief comment, see Furlong, Nacimiento y desarrollo (Ref. 8), pp. 507-8.

${ }^{80}$ The titles of the sections are "De Deo ut est primum principium effectivum in creatione", "De operibus primo die creatis", "De caeteris rebus in quinque subsequentibus diebus creatis" (Juan Fernández, Conclusiones [Ref. 79], pp. 8-11).

81 Juan Fernández, Conclusiones (Ref. 79), p. 9.

${ }^{87}$ Juan Pabst, "Introducción," in Facultad de Filosofía y Letras (UBA), Instituto de Investigaciones Históricas, Documentos para la Historia Argentina, t. XVIII, Cultura. La enseñanza durante la época colonial (1771-1810) (Buenos Aires: Peuser, 1924), pp. xi-ccxii, in pp. cxxvii-cli; Antonino Salvadores, "Real Colegio de San Carlos," in Ricardo Levene (ed.), Historia de la Nación Argentina 3a ed. (Buenos Aires: El Ateneo 1961, 11 vols.), vol. 4.2, pp. 125-31.

${ }^{83}$ The theses, defended by Gregorio García de Tagle and Dámaso Larrañaga, were edited in Latin with a Spanish translation in Zuretti, "Tesis sobre filosofía y ciencias, defendidas en 1792 en el real Colegio de San Carlos en Buenos Aires," Revista de la Universidad de Buenos Aires, 44, 331, 1948, pp. 515-53, in pp. $526-53$. Melchor Fernández also prepared a set of Theses ex universa theologia defended in 1795 by Mariano Irigoyen. Fernández arrived as a child in Buenos Aires in 1772. He attended the Colegio de San Carlos and studied in the University of San Javier (Chuquisaca), where he graduated as doctor in theology in 1786; the next year he was ordained as a priest in Asunción. After teaching philosophy, he got the chairs of Moral Theology and Theology (1804) and was eventually nominated archdeacon of the Cathedral of Buenos Aires. Furlong, Nacimiento $y$ desarrollo (Ref. 8), pp. 320-7 and 491-7.

${ }^{84}$ Zuretti, “Tesis sobre filosofía y ciencias" (Ref. 83), p. 541.

85 José Valentín Gómez, Conclusiones ex universa philosophia (Buenos Aires: Apud Regiam Parvulorum Orphanorum Typographiam, 1802). The students who defended the theses were Gregorio Echagüe, Manuel de García, and Matías Patrón. See Furlong, Nacimiento y desarrollo (Ref. 8), pp. 370-7 and 500-505. Valentín Gómez, born in Buenos Aires, studied in San Carlos, Córdoba (Theology) and Chuquisaca (Civil and Canon Law). He was ordained in 1799.

${ }^{86}$ Furlong, Nacimiento y desarrollo (Ref. 8), pp. 370 and 372.

${ }^{87}$ Gómez, Conclusiones ex universa philosophia (Ref. 85), p. 13.

${ }^{88}$ This may be attributed to direct copy or to the use of the same handbook.

${ }^{89}$ For a brief account and bibliography in these schools, see Asúa, La ciencia de Mayo (Ref. 5), pp. 19-33 and 155-60.

${ }^{90}$ Enrique Udaondo, Diccionario Biográfico Colonial Argentino (Buenos Aires: Huarpes, 1945), pp. 245-6; Guillermo Vázquez Rivarola, Cerviño, hijo de Galicia, padre de Argentina (Vigo: Grupo de Comunicación de Galicia en el Mundo, 2009).

${ }^{91}$ Antonio Lafuente "Las Academias Militares y la inversion en ciencia en la España ilustrada (1750-1760)," Acta Hispanica ad Medicinae Scientarumque Historiam Illustrandam, 2, 1982, pp. 193-209.

92 Pedro Cerviño, "Prolusión académica. Discurso en que se procura que para ser buen piloto es necesaria la astronomía", in Nicolás Besio Moreno, Las fundaciones matemáticas de Belgrano (Buenos Aires: Instituto Nacional Belgraniano, 1995), pp. 173-8, in p. 176. 
${ }^{93}$ Cerviño, "Prolusión académica" (Ref. 92), p. 174.

${ }^{94}$ Cerviño, "Prolusión académica" (Ref. 92), p. 174.

${ }^{95}$ See Cerviño, "Proyecto de organización y plan de enseñanza de la Academia", in Besio Moreno, Las

fundaciones matemáticas (Ref. 92), pp. 149-57, in p. 150. It is not clear whether he was thinking of Cours de mathématiques à l'usage des Gardes du Pavillon et de la Marine, 6 vols. (Paris: 1764-1769) or of the Cours complet de matématiques, à l'usage de la marine et de l'artillerie, 6 vols. (Paris, 1780).

${ }^{96}$ Germán O. E. Tjarks, El Consulado de Buenos Aires y sus proyecciones en la historia del Río de la Plata (Buenos Aires: Universidad de Buenos Aires, Facultad de Filosofía y Letras, 1962, 2 vols.), vol. 2, p. 834. Benito Bails, Principios de matemática de la Real Academia de San Fernando, $2^{\text {nd }}$ ed. (Madrid: Viuda de Ibarra, 1790, 3 vols.).

${ }^{97}$ Bails, Principios (Ref. 96), vol. 3, pp. iii-xxiii. Cerviño was also acquainted with the praise of astronomy in Lalande's Astronomie. The former used as title of his conference on 15 November 1799 inaugurating the courses of the Nautical Academy a Spanish translation of a verse of Antoine-Marin Lemierre, "le trident de Neptune est le sceptre du monde", which in all likelihood he took from Lalande. Pedro Cerviño, "El tridente de Neptuno es el cetro del mundo", in Besio Moreno, Las fundaciones matemáticas de Belgrano (Ref. 92), pp. 159-73; cf. Joseph Jérôme Lalande, Astronomie (Paris: Desaint et Saillant, 1764, 2 vols.), vol. 1, p. xxv.

${ }^{98}$ Benito Bails, Elementos de matemáticas (Madrid: Joaquín Ibarra, 1775, 10 vols.), vol. 7, pp. iii-xxvi.

${ }^{99}$ Asúa, La ciencia de Mayo (Ref. 5), p. 61.

${ }^{100}$ Tjarks, Consulado (Ref. 96), vol. 2, p. 835.

${ }^{101}$ Mariano Hormigón, Las matemáticas en el siglo XVIII (Madrid: Akal, 1994), p. 50

102 Juan Antonio Llorente, Historia Crítica de la Inquisición de España (Madrid: Imprenta del Censor, 1822), vol. 5, pp. 163-4. See also Claude Bédat, "Don Benito Bails", Academia. Anales y Boletín de la Real Academia de Bellas Artes de San Fernando 27, 1968, pp. 19-50. For Bail's library, see Inmaculada Arias de Saavedra Alías, "Libros extranjeros en la biblioteca del matemático Benito Bails (1731-1797)," in M. B. Villar García and P. Pezzi Cristóbal (eds.), Los extranjeros en la España moderna. Actas del I Coloquio Internacional celebrado en Málaga del 28 al 30 de noviembre de 2002 (Málaga: s/d, 2003, 2 vols.), vol. 2, pp. 125-37, in p. 128.

${ }^{103}$ Bails, Principios (Ref. 96), vol. 3, p. 329.

${ }^{104}$ Bails, Principios (Ref. 96), vol. 3, pp. 348-9.

${ }^{105}$ Bails, Elementos (Ref. 98), vol. 7, p. 90.

${ }^{106}$ Vernet, "Copernicus in Spain" (Ref. 65), pp. 286-8.

${ }^{107}$ Susan Migden Socolow, The Merchants of Buenos Aires, 1778-1810. Family and Commerce. Cambridge: Cambridge University Press, 1978.

${ }^{108}$ This book was used as a source by the Jesuit teachers of the Collegio Romano during the seventeenth century, see Raphael (Ref. 8), "Copernicanism," p. 429.

${ }^{109}$ See Marcela Ternavasio, "José Valentín Gómez," in Nancy Calvo, Roberto Di Stefano, and Klaus Gallo (eds.), Los curas de la Revolución (Buenos Aires: Emecé, 2002), pp. 171-200. For Fr. Cayetano's life, see Ambrosio Romero Carranza, "Fray Cayetano Rodríguez," in Federico Videla Escala et al., El Congreso de Tucumán: actitudes, decisiones, hombres (Buenos Aires: Club de Lectores, 1966), pp. 241-90. 